\title{
PENGARUH KINERJA KEUANGAN TERHADAP HARGA SAHAM PADA PERUSAHAAN PERBANKAN YANG TERDAFTAR DI BURSA EFEK INDONESIA
}

\author{
Nurjannah Waris \\ Prodi Manajemen FEB UMM \\ E-mail: nurjannahwaris@gmail.com
}

\begin{abstract}
This research aims to test the influence of corporate financial performance of banking corporate proxied on CAR, NPL, NIM, ROA, ROE, LDR, BOPO against stock prices on corporate banking in Indonesia stock exchange simultaneously and partial. The population in this study is banking company in Indonesia Stock Exchange amounted to 36 banks. Samples was determined by the method of purposive sampling in order to obtain 23 sample companies. The results of this research show that partially contributing significantly to the stock price is the NPL, ROA, and LDR. As for the CAR, ROE, NIM, BOPO had no significant effect on stock prices. Simultaneously shows there is influence between all independent variables on stock prices. The magnitude of the effect was 31,7\% while the rest of $68,3 \%$ influenced other factors outside of research. The implications of this research shows that financial performance on certain conditions, have no effect on the decisions of investors in the capital markets.
\end{abstract}

Keywords: Financial Performance, Stock Prices, Banking

\section{PENDAHULUAN}

Keberhasilan perekonomian di Indonesia tidak terlepas dari sektor perbankan. Hal ini dikarenakan perusahaan perbankan adalah lembaga yang berperan dalam sumber pembiayaan yang mempertemukan pihak-pihak yang membutuhkan modal dengan pihak yang memiliki modal.

Bank dikenal sebagai lembaga keuangan yang kegiatan utamanya menerima simpanan giro, tabungan, dan deposito atau dikenal dengan istilah funding, juga menerbitkan saham, obligasi, polis, program pensiun dan lain-lain. Bank juga dikenal sebagai tempat untuk meminjam uang (kredit) bagi masyarakat yang membutuhkannya.

Kinerja perbankan nasional tetap terjaga stabilitasnya dan sehat dengan fungsi intermediasi yang terus meningkat dalam mendukung pembiayaan perekonomian (www.antaranews.com).

Secara umum kinerja industri
perbankan semakin solid
sebagaimana tercermin pada
tingginya rasio kecukupan modal
(CAR) dan rasio kredit bermasalah
(NPL) yang rendah. Selain itu juga
ditandai oleh banyaknya bank yang
memiliki modal inti $\geq$ Rp 100 miliar,


$\mathrm{CAR} \geq 12 \%, \mathrm{NPL}<5 \%, \mathrm{ROA} \geq 1,5 \%$ dan LDR $\geq 50 \%$ (Biro Riset BUMN Center LM FEUI).

Ketika perbankan-perbankan di belahan dunia, khususnya zona Eropa mengalami penurunan rating atau downgrade, perbankan di tanah air justru sebaliknya. Kinerja perbankan relatif baik dan tidak seperti kondisi pada 1998 atau 2008. Saat ini perbankan menjadi motor penggerak ekonomi nasional. Industri perbankan selama periode 2012 mencatat kinerja yang cukup baik terlihat dari perolehan laba yang meningkat 21,58\% menjadi Rp 95,30 triliun.

Pencapaian laba ini dicatat sebagai rekor tertinggi laba industri perbankan. Intermediasi perbankan semakin membaik tercermin dari pertumbuhan kredit yang mencapai $24,77 \%$. Industri perbankan nasional juga mengalami peningkatan dana pihak ketiga yang mencapai 16,29\% (infobanknews.com).

Peningkatan kinerja industri perbankan nasional beberapa tahun terakhir seiring dengan bertambahnya jumlah emiten perbankan yang tercatat di Bursa Efek Indonesia. Peningkatan jumlah emiten berdampak baik bagi pihak-pihak yang berkepentingan, antara lain perusahaan akan lebih mudah mendapatkan modal, dan bagi investor akan mendapatkan return. Akan tetapi, investasi dalam bentuk saham mempunyai risiko yang tinggi sesuai dengan prinsip investasi yaitu low risk low return, high risk high return.

Dalam pengambilan keputusan investasi saham, investor lebih memilih saham yang memberikan return tinggi. Investor dapat menilai kemampuan perusahaan yang bisa memberikan return berdasarkan laporan kinerja keuangan. Kinerja keuangan bank merupakan bagian dari kinerja bank secara keseluruhan. Kinerja bank secara keseluruhan merupakan gambaran presentase yang dicapai bank dalam operasionalnya, baik menyangkut aspek keuangan, pemasaran, maupun sumber daya manusia (Abdullah, 2003: 108).

Apabila kinerja keuangan dinyatakan baik, maka kemungkinan laba yang diperoleh perusahaan meningkat, dan dividen yang akan dibagikan kepada pemegang saham akan mengalami kenaikan pula. Tingginya daya beli saham menandakan tingginya permintaan dan berdampak pada naiknya harga saham. Sebaliknya apabila kinerja buruk, para investor cenderung tidak membeli saham dan keputusan akhir yaitu menjual saham. Dengan menjual saham makan penawaran akan meningkat, hal ini berdampak pada turunnya harga saham.

Perusahaan harus memiliki data atas kondisi perusahaan yang memiliki tren positif agar dapat bertahan dan beroperasi, serta merangsang para kreditur dan pemegang saham untuk berinvestasi dan menanamkan modalnya. Data tersebut akan dijadikan acuan dan tolak ukur para investor. Selain bagi pihak ekstern, pengukuran kinerja keuangan ini juga sangat penting dan berguna khususnya bagi pihak intern perusahaan sebagai alat pengambilan keputusan dan rencana operasional perusahaan di masa yang akan datang.

Kinerja keuangan perbankan dapat dinilai dengan menggunakan pendekatan analisis rasio keuangan. 
Rasio keuangan ini berfungsi sebagai ukuran dalam menganalisis laporan keuangan suatu perusahaan. Rasio keuangan yang digunakan untuk menilai kinerja perusahaan perbankan umumnya digunakan aspek penilaian menggunakan metode CAMELS (Capital, Assets quality, Management, Earnings, Liquidity, dan Sensitivity to market risk), yang mengacu pada Surat Edaran BI No.6/23/DPNP tanggal 31 Mei 2004 tentang Tata Cara Penilaian Kesehatan Bank dan Peraturan BI No. 6/10/PBI/2004 tentang Sistem Penilaian Tingkat Kesehatan Bank Umum. Hal ini menunjukan bahwa rasio keuangan dapat digunakan untuk menilai tingkat kesehatan bank. Pertimbangan untuk mengangkat penelitian tentang rasio keuangan perbankan dalam kaitannya dengan harga saham adalah sahamsaham perusahaan perbankan yang diperdagangkan di BEI pada umumnya sangat peka terhadap gejolak indikator makro seperti tingkat inflasi, suku bunga, kurs valas, dan kebijakan moneter. Selain faktor tersebut, kinerja bank diasumsikan berpengaruh terhadap harga saham. Pertimbangan lainnya adalah rasio keuangan perbankan sedikit berbeda dengan rasio keuangan jenis perusahaan lain (Pernyataan Standar Akuntansi No. 31/2002).

Berdasarkan latar belakang di atas, maka penulis terdorong melakukan penelitian skripsi dengan judul: "Pengaruh Kinerja Keuangan terhadap Harga Saham pada Perusahaan Perbankan yang Tercatat di Bursa Efek Indonesia".

\section{TINJAUAN PUSTAKA}

Keberhasilan perusahaan
dalam menjalankan aktivitasnya
dapat dilihat melalui prestasi kerja perusahaan/ kinerja perusahaan. Kinerja adalah suatu usaha formal yang dilaksanakan perusahaan untuk mengevaluasi efisien dan efektivitas dari aktivitas perusahaan yang telah dilaksakanan pada periode waktu tertentu (Hanafi dan Halim, 2003:69).

Kinerja perusahaan dapat diukur dari laporan keuangan yang dikeluarkan secara periodik, laporan berupa neraca, laba rugi, arus kas, dan perubahan modal yang secara bersama-sama memberikan suatu gambaran tentang posisi keuangan perusahaan. Salah satu metode yang ditetapkan oleh Bank Indonesia dalam pengukuran kesehatan suatu bank adalah menggunakan rasio CAMELS. Analisis ini terdiri dari aspek capital, assets, management, earning, liquidity, dan sensitivity. Hasil dari masing-masing aspek ini kemudian akan menghasilkan kondisi suatu bank (Kasmir, 2004:50). Husnan (2001: 303) menyebutkan bahwa sekuritas (saham) merupakan secarik kertas yang menunjukkan hak pemodal (yaitu pihak yang memiliki kertas tersebut) untuk memperoleh bagian dari prospek atau kekayaan organisasi yang menerbitkan sekuritas tersebut dan berbagai kondisi yang memungkinkan pemodal tersebut menjalankan haknya.

Harga saham adalah nilai suatu saham yang mencerminkan kekayaan perusahaan yang mengeluarkan saham tersebut, dimana perubahaan 
atau fluktuasinya sangat ditentukan oleh kekuatan permintaan dan penawaran yang terjadi di pasar bursa (pasar sekunder). Semakin banyak investor yang ingin membeli atau menyimpan saham, harganya semakin naik. Sebaliknya semakin banyak investor yang ingin menjual atau melepaskan suatu saham, maka harganya semakin bergerak turun.

Halim (2005: 21) menyatakan bahwa saham memiliki nilai intrinsik tertentu (nilai yang seharusnya). Nilai instrinsik suatu saham ditentukan oleh faktor-faktor fundamental yang mempengaruhinya. Ide dasar pendekatan ini adalah harga saham akan dipengaruhi oleh kinerja perusahaan. Apabila kinerja perusahaan baik maka nilai usaha akan tinggi. Dengan nilai usaha yang tinggi membuat para investor melirik perusahaan tersebut untuk menanamkan modalnya sehingga akan terjadi kenaikan harga saham.

\section{METODE PENELITIAN}

Jenis penelitian yang digunakan adalah penelitian deskriptif yang bertujuan untuk menjelaskan karakteristik suatu fenomena yang dapat digunakan sebagai dasar pembuatan keputusan untuk memecahkan masalah penelitian. Data yang digunakan dalam penelitian ini adalah data sekunder. Data sekunder merupakan pendekatan penelitian yang menggunakan data-data yang telah ada, selanjutnya dilakukan proses analisa terhadap data-data tersebut sesuai dengan tujuan penelitian.

Data yang digunakan berupa laporan keuangan tahunan yang dipublikasikan oleh perusahaan perbankan yang terdaftar di Bursa
Efek Indonesia (BEI) tahun 20102012, data harga saham penutupan harian masing-masing perusahaan perbankan yang menjadi sampel penelitian yang dapat diunduh dari website Bursa Efek Indonesia.

Variabel dibedakan menjadi dua yaitu variabel dependen (variabel terikat) dan variabel independen (variabel bebas). Variabel dependen dalam penelitian ini adalah harga saham. Harga saham yang digunakan sebagai dasar perhitungan adalah harga saham penutupan harian perusahaan perbankan setelah diterbitkannya laporan keuangan perusahaan perbankan di Bursa Efek Indonesia (BEI) periode 2010-2012. Variabel bebas dalam penelitian ini adalah kinerja keuangan peusahaan perbankan yang diproksikan dengan rasio keuangan sebagai berikut: Capital Adequancy Ratio (CAR), Non Performing Loan (NPL) Net Interest Margin (NIM), Return on Asset (ROA), Return on Equity (ROE), Beban Operasional terhadap Pendapatan Operasional (BOPO), Loan to Deposit Ratio (LDR), Populasi yang menjadi subjek dalam penelitian ini adalah seluruh perusahaan perbankan yang terdaftar di Bursa Efek Indonesia. Berdasarkan data yang diperoleh, populasi penelitian yang terdiri dari 36 perusahaan perbankan.

Sampel adalah sebagian atau wakil populasi yang diteliti (Arikunto, 2002: 109). Teknik pengambilan sampel dalam penelitian ini yaitu dengan menggunakan purposive sampling. Purposive Sampling adalah teknik pengambilan sampel tidak secara acak melainkan dengan pertimbangan tertentu dari populasi. 
Teknik analisis yang digunakan adalah: pertama analisis statistik deskripif memberikan gambaran atau deskripsi suatu data yang dilihat dari mean, standar deviasi, varian, maksimum, minimum, sum, range, kurtosis, dan skewness. Kedua, Uji normalitas data yang bertujuan untuk menguji apakah dalam model regresi, variabel pengganggu atau residual memiliki distribusi normal. Mendeteksi normalitas data dapat dilakukan dengan uji Kolmogorov-Smirnov.

Ketiga, analisis regresi berganda untuk mengestimasi atau memprediksi rata-rata populasi atau nilai rata-rata nilai variabel dependen berdasarkan nilai variabel independen yang diketahui (Gujarati, 2003: 72). Persamaan regresi linier ganda adalah sebagai berikut:

$Y=\alpha+\beta_{1} X_{1}+\beta_{2} X_{2}+\beta_{3} X_{3}+\beta_{4} X_{4}+$ $\beta_{5} X_{5}+\beta_{6} X_{6}+\beta_{7} X_{7}+e$

Keterangan:

$\mathrm{Y}=$ Harga Saham

$\mathrm{a}=$ Bilangan Konstanta

$\beta_{1}-\beta_{6}=$ Koefisien regresi

$\mathrm{X}_{1}=$ Capital Adequancy Ratio (CAR)

$\mathrm{X}_{2}=$ Non Performing Loan (NPL)

$\mathrm{X}_{3}=$ Net Interest Margin (NIM)

$\mathrm{X}_{4}=$ Return on Asset (ROA)

$\mathrm{X}_{5}=$ Return on Equity (ROE)

$\mathrm{X}_{6}=$ Beban Operasional terhadap

Pendapatan Operasional (BOPO)

$\mathrm{X}_{7}=$ Loan to Deposit Ratio (LDR)

$\mathrm{e}=$ Residual

Keempat, uji asumsi klasik

untuk mengetahui apakah model regresi benar-benar menunjukkan hubungan yang signifikan dan representatif, maka model tersebut harus memenuhi asumsi klasik regresi. Uji asumsi klasik yang dilakukan adalah multikolinearitas, uji autokorelasi, dan uji heteroskedastisitas.

Kelima, uji hipotesis yang terdiri dari Uji $F$ untuk menguji hipotesis antara lebih dari satu variabel independen terhadap satu variabel dependen, Uji $\mathrm{t}$ untuk menguji hipotesis antara satu variabel independen dengan satu variabel dependen dan Uji Koefisien Determinasi $\left(\mathrm{R}^{2}\right)$, untuk melihat prosentase pengaruh variabel independen yang dimasukkan dalam penelitian terhadap variabel dependen.

\section{HASIL PENELITIAN DAN PEMBAHASAN}

Sampel yang digunakan dalam penelitian ini ditentukan dengan menggunakan purposive sampling. Berdasarkan proses seleksi diperoleh sebanyak 23 perusahaan perbankan yang dipilih sebagai sampel dari 36 perusahaan yang terdaftar di Bursa Efek Indonesia. Statistik deskriptif memberikan gambaran atau deskripsi bahwa hanya nilai CAR semua perusahaan sampel yang memenuhi batas minimum yang ditetapkan oleh Bank Indonesia sedangkan variabel lainnya masih ada beberapa sampel yang tidak memenuhi batas minimum.

Hasil output KolmogorovSmirnov dapat dilihat pada asymp. Sig. (2-tailed) variabel NIM nilainya $0.002(<0.005)$ dan Harga Saham nilainya $0.000(<0.05)$. Hasil tersebut menunjukkan bahwa data dari variabel NIM dan Harga Saham tidak berdistribusi normal. Oleh karena itu, data yang tidak terdistribusi normal dapat ditransformasi agar menjadi normal dengan Lg 10. Setelah melakukan transformasi, hasil uji 
Kolmogorov-Smirnov untuk variabel NIM nilainya $0.86 \quad(>0.05)$ dan variabel harga saham nilainya 0.079 $(>0.05)$.

$$
\text { Berdasarkan perhitungan }
$$

komputer program statistik SPSS 16.00 for windows diperoleh persamaan regresi linear berganda sebagai berikut:

YHS $=1,893+0,029 \mathrm{CAR}-$ $0,023 \mathrm{NPL}+0,097 \mathrm{NIM}+0,028 \mathrm{ROA}$ $+0,015 \mathrm{ROE}+0,021 \mathrm{BOPO}+$ 0,017LDR $X_{t-1}$

Dari persamaan regresi di atas, maka dapat diketahui bahwa persamaan regresi dengan panjang lag optimal dengan variabel lag 1 karena konstanta LDR yang nilainya negatif mengalami perubahan dari menjadi positif.

Uji asumsi klasik yang dilakukan dalam penelitian ini adalah multikolinearitas, autokorelasi, dan heteroskedastisitas. Multikolinearitas terjadi jika nilai VIF (varian inflation factor) $>10$; dan jika tolerance $<0,1$. Dalam hal ini seluruh variabel dalam penelitian ini bebas dari masalah multikolinearitas. Untuk autokorelasi terlihat angka D-W sebesar 2,394. Angka ini terletak antara du $(1,80279)$ dan 4-du (2,6047), maka hal ini berarti pada model regresi tidak ada autokorelasi positif atau negatif, atau dapat disimpulkan tidak terdapat autokorelasi. Jika tidak ada pola yang jelas, serta titik-titik menyebar di atas dan di bawah angka 0 pada sumbu Y, maka tidak terjadi heteroskedastisitas.

Untuk Uji F, dari hasil perhitungan juga dapat dilihat $F_{\text {hitung }}$ sebesar 3,893 dengan $F_{\text {tabel }}$ 2,25141 dengan kata lain $F_{\text {hitung }}>F_{\text {tabel }}$. Hal ini berarti variabel secara bersama-sama (simultan) berpengaruh signifikan terhadap harga saham perusahaan perbankan di Bursa Efek Indonesia.

Untuk Uji t pengambilan keputusan didasarkan pada probabilitas signifikansi $0,05(5 \%)$. Dari seluruh variabel yang dinyatakan signifikan berpengaruh terhadap harga saham adalah NPL, ROA dan LDR karena signifikansi lebih kecil atau sama dengan $0.05(\leq 0.05)$.

Nilai koefisien determinasi simultan $\left(\mathrm{R}^{2}\right)$ diperoleh sebesar 0,317 . Nilai tersebut menunjukkan seluruh variabel independen secara simultan mempengaruhi harga saham sebesar $31,7 \%$ dan sisanya sebesar $68,3 \%$ dipengaruhi oleh faktor lain yang tidak dikaji dalam penelitian ini.

Hasil penelitian pengaruh secara parsial menunjukkan bahwa NPL, ROA, dan LDR berpengaruh signifikan terhadap harga saham. NPL (Non-Performing Loan) merupakan rasio yang menunjukan bahwa kemampuan manajemen bank dalam mengelola kredit bermasalah yang diberikan oleh bank. Persyaratan yang ketat dalam kebijakan kredit akan mengurangi kemungkinan terjadinya kredit bermasalah.

ROA (Return on Asset) merupakan rasio yang mengukur kemampuan bank dalam menghasilkan laba. Untuk dapat mempertahankan kelangsungan hidupnya, perusahaan memerlukan laba. Laba ini akan diperoleh jika perusahaan mampu memasarkan atau menjual barang-barang yang dihasilkan atau barang-barang yang ditawarkan. Dengan kondisi yang demikian itu perusahaan mampu memberikan informasi laporan 
keuangan yang berdaya guna sebagai alat bantu pengambilan keputusan.

LDR (Loan to Deposit Ratio) juga berpengaruh signifikan terhadap harga saham secara parsial. Hal ini sesuai dengan penelitian yang dilakukan oleh Ardiani (2007) dan Fajrin (2011). LDR menggambarkan kemampuan bank membayar kembali penarikan yang dilakukan nasabah deposan dengan mengandalkan kredit yang diberikan sebagai sumber likuiditas. Semakin tinggi rasio LDR semakin rendah pula kemampuan likuiditas bank. LDR yang tinggi berarti resiko dalam berinvestasi menjadi tinggi. Likuiditas bank yang rendah maka hal tersebut akan berdampak pada hilangnya kepercayaan investor.

\section{SIMPULAN}

Secara simultan, seluruh variabel independen yang terdiri dari Capital Adequacy Ratio (CAR), Non-Performing Loan (NPL), Net Interest Margin (NIM), Return on Asset (ROA), Return on Equity (ROE), Beban Operasional terhadap Pendapatan Operasional (BOPO), dan Loan to Deposit Ratio (LDR) berpengaruh terhadap harga saham perusahaan perbankan. Secara parsial, variabel independen yang berpengaruh secara signifikan terhadap harga saham adalah NPL, ROA dan LDR sedangkan CAR, NIM, ROE, dan BOPO tidak berpengaruh signifikan terhadap harga saham.

Besar pengaruh CAR, NPL, NIM, ROA ROE, BOPO dan LDR terhadap harga saham perusahaan perbankan di Bursa Efek Indonesia adalah $31,7 \%$, sedangkan sisanya $68,3 \%$ dipengaruhi variabel lain di luar penelitian.

Adapun saran yang dapat peneliti berikan diantaranya: Harga saham juga dipengaruhi oleh faktor eksternal seperti inflasi, tingkat suku bunga, kurs valas, volume transaksi dan kondisi lingkungan yang mencakup kestabilan ekonomi dan politik. Oleh karena itu, calon investor sebaiknya memperhatikan faktor eksternal tersebut sebagai bahan pertimbangan analisa sebelum mengambil keputusan investasi pada saham.

Bagi pihak perusahaan perbankan yang telah menjual sahamnya, hendaknya lebih meningkatkan nilai kinerja keuangan perusahaan. Khususnya menyangkut penelitian ini memperhatikan rasio yang mempunyai pengaruh signifikan yaitu NPL, ROA, dan LDR. Sehingga perusahaan hendaknya mempertahankan nilai rasio di atas standart BI dan melakukan efisiensi pada kredit bermasalah, peningkatan asset, dan tingkat likuiditasnya.

Bagi peneliti lain yang hendak melakukan penelitian sejenis, sebaiknya menggunakan variabel berbeda dari penelitian sebelumnya untuk mengetahui faktor yang mempengaruhi harga saham dari segi fundamentalnya. Selain faktor internal seperti kinerja perusahaan, peneliti selanjutnya bisa mengambil faktor dari eksternal perusahaan misalnya inflasi, tingkat suku bunga, kurs valas, volume transaksi dan kondisi lingkungan agar memperoleh hasil yang lebih akurat. 
DAFTAR PUSTAKA

Algifari. 2000. Analisis Regresi, Teori, Kasus dan Solusi. Edisi Kedua. Yogyakarta: BPFE

Ardiani, Anita. 2007. Analisis Pengaruh Kinerja Keuangan terhadap Perubahan Harga Saham pada Perusahaan Perbankan di Bursa Efek Jakarta (BEJ). Semarang. Universitas Negeri Semarang.

Arikunto, Suharsimi. 2002. Prosedur Penelitian Sutu Pendekatan Praktek. Jakarta: Rineka Cipta.

Bratadharma, Angga. 2013. Perbankan Masih Jauh dari Krisis.

(http://www.infobanknews.co m/2013/11/perbankan-masihjauh-dari-krisis, diakses pada 1 Maret 2014)

Fajrin. 2011. Pengaruh Kinerja Keuangan terhadap Harga Saham pada Perusahaan Perbankan yang Terdaftar di Bursa Efek Indonesia (BEI). Malang. Universitas Muhammadiyah Malang.

Fakhrudin dan Hadianto, Sopian. 2001. Perangkat dan Model Analisis Investasi di Pasar Modal. Jakarta: Elex Media Komputindo.

Ghozali, Imam. 2011. Aplikasi Analisis Multivariate dengan Program IBM SPSS 19. Semarang : Badan Penerbit Universitas Diponegoro.

Hanafi, Mamduh dan Halim, Abdul. 2003. Analisis Laporan Keuangan. Yogyakarta: UPP AMP YKPN.

Gujarati, Damodar. 2003. Ekonometrika Dasar Edisi Keenam. Jakarta: Erlangga.
Halim, Abdul. 2005. Analisis Investasi. Jakarta: Salemba Empat.

Hasibuan, H. Malayu. 2006. DasarDasar Perbankan. Jakarta: PT Bumi Aksara.

Husnan, Suad. 2003. Dasar-Dasar Teori Portofolio dan Analisis Sekuritas Edisi Ketiga. Yogyakarta: UPP AMP YKPN.

Kasmir. 2004. Bank dan Lembaga Keuangan Lainnya. Jakarta: PT Raja Grafindo Persada.

Kuncoro, Mudrajat dan Suhardjono. 2002. Manajemen Perbankan: Teori dan Aplikasi. Yogyakarta: BPFE.

Munawir. 2007. Analisis Laporan Keuangan. Yogyakarta: Liberty.

Mulyadi. 2001. Sistem Akuntansi Edisi Ketiga. Jakarta: Salemba.

Saputra, Desy. 2012. BI Nilai Kinerja Perbankan Membaik. (http://www.antaranews.com/b erita/315559/bi-nilai-kinerjaperbankan-membaik, diakses pada 1 Maret 2014).

Siamat, Dahlan. 2005. Manajemen Lembaga Keuangan Edisi Kelima. Jakarta: Lembaga Penerbitan FE UI

Surat Edaran BI No. 6/ 23/ DPNP tanggal 31 Mei 2004 tentang Tata Cara Penilaian Kesehatan Bank.

Weston J. Fred dan Eugene F. Brigham. 1993. Dasar-dasar Manajemen Keuangan Jilid 2 Edisi Kesembilan. Jakarta: Erlangga 
